\title{
Should Slovenia Transform the Accounting in Public Sector?
}

\author{
Tatjana Jovanović \\ University of Ljubljana, Faculty of Public Administration, Slovenia \\ tatjana.jovanovic@fu.uni-lj.si
}

\section{ABSTRACT}

Even before, but especially in time of financial and economic crisis, countries are facing a challenge to improve the information served by public accounting for the state budgeting purpose, most often by reforming accounting principle from cash flow into accrual. The majority of literature impose the opinion that the accrual accounting facilitates more transparent and complete review of the business activities and property of the users of public funds than cash principle does and that additionally provides more transparent budgeting. The article evaluates the pros and cons of the public sector accounting transformation in Slovenia using arguments for a simple SWOT analysis in experience of other countries, presented in the literature.

Keywords: public sector accounting, budget accounting, accrual principle, cash principle, accounting reforms

JEL: H83

\section{Introduction}

The public sector accounting can be described as a system which gathers, records, classifies and summarizes reports of the financial events existing in the public sector and as required by accountability and financial transparency provides information to users associated to public institutions (Кага, 2012, p. 82). It represents the accounting systems of public sector entities. The public sector entities are entities that implement public policy through the provision of primarily nonmarket services and the redistribution of income and wealth, with both activities supported mainly by compulsory levies on other sectors. The public sector consists of governments and all publicly controlled or publicly funded agencies, enterprises, and other entities that deliver public programs, goods, or services (The Institute of Internal Auditors, 2011).

The global economic crisis has underscored the importance of accountable and transparent use of public funds, in particular in light of deteriorating fiscal position and rising public debts. There is now a growing consensus that good information on government activities matters. It can help policy makers

Jovanović, T. (2015). Should Slovenia Transform the Accounting in Public Sector? International Public Administration Review, 13(3-4), 67-82. 
to better navigate their reform agenda. Public and financial institutions require it too, amid increased concerns over sustainability of public accounts. In addition, businesses need it for their strategy planning. Overall, public sector accounting and budgeting systems can either strengthen or weaken the trust, which underpins relations in a society (CEF, 2011). If ever it is now clear that it is the time to establish requirements for greater transparency and accountability in public finance. Many developed countries have gone through gradual or radical change of public sector accounting where traditional cash flow public accounting has been changed with accrual based public accounting. There are also many developing and transitional countries that have accelerated public sector reform by introducing accrual or some kind of modified accrual or cash accounting (Hepworth, 2003).

The paper's objective is to analyse the potentials for implementation of new accounting model in public sector concerning the knowledge and experiences of other countries (case studies) and focusing on accounting principle implementation. The methodology will base on the SWOT analysis, added by several recommendations based on comparative review of the literature.

\section{Literature and Regulation Review}

Many countries have gone through a radical wave of organizational, managerial and accounting reform in the public sector in the last 20 years. The accounting systems reforms were part of the general public sector management reforms, more known as the concept of New Public Management (NPM). The public sector has been subjected to transformations in order to enhance the efficiency and accountability of public service delivery (Barton, 2004; Broadbent \& Guthrie, 1992; Burkitt \& Whyman, 1994). NPM has its background in the reforms that were carried out in United Kingdom during the Thatcher era and were seen as highly political and ideological at that time. Over the years, the ideological element of the reforms has been deemphasised and the idea has become a trend. The public sector accounting reform has presented the idea of transferring the accounting from cash flow to accrual principles and shifting from a cash flow and cash balances concept to a total-economic resources concept. Nevertheless, there has been a great focus on the reforms and transformations of the accounting principles (accrual/cash) in the literature; the transformations included also other categories of the accounting. Consequently, the governmental accounting diverges between countries and within countries of EU. The diversity ranges from fundamental differences in recording systems to different measurement rules and disclosure requirements (Grossi \& Soverchia, 2011). Contrary to the majority of the literature that highlights public accounting reforming trend, the newest publications recognize that most reforms have been largely a product of individual countries, both in the decision on scope and timing and in implementation choices (Brusca, Caperchione, Cohen, \& Manes Rossi, 2015). 
The study of Lüder and Jones (2003) proves that several European countries have gone through government accounting reforms focusing on introduction of accrual-based accounting in governmental organizations. Additionally, in year 2000 the international study (Brusca \& Candor, 2002) identifies that the accrual accounting principle predominates in Anglo-Saxon countries, while Continental European countries were still in the process of converting to accrual accounting, by adopting modified cash and modified accrual systems instead of complete or full accrual systems (Vašiček, Vašiček, \& Roje, 2008). The Continental accounting tradition (called also managerialism-driven) can be associated with French, German and Roman legal systems, while the AngloSaxon accounting tradition (called also accountabilism-driven) is normally linked with the common law legal system family (Grossi \& Soverchia, 2011, p. 526).

IFAC-PSC (International Federation of Accountants Public Sector Committee ${ }^{1}$ ) identifies four different bases of accounting: cash, modified cash, modified accrual and full accrual. Cash and accrual represent two ends on a spectrum of possible accounting and budgeting bases. Traditionally, the cash end of the spectrum has been applied by OECD member countries for their public sector activities. A modified cash accounting system recognizes transactions and other events on a cash basis during the year, but it also takes into account the unpaid accounts and/or receivables at year's end. In fact, the books are held open for around a month after year end while a modified accrual accounting system recognizes transactions and other events on an accrual basis, but certain classes of assets or liabilities are not recognized. A typical example is the expensing of all non-financial assets at the time of purchase (Christiaens \& Reyniers, 2009).

In recent years, there has been a major trend towards the accruals end of the spectrum in member countries. About half of member countries have adopted accruals to one degree or another (Richard, 2002; Christiaens, 1999). However, cash accounting is still used for reporting purpose in many countries. This phenomenon is a clear indication that cash accounting serves some purposes that are not adequately covered by accrual accounting. The review of the international literature on government accounting reform reveals that the various scientific research contributions are categorized mainly within the three types (Jovanović, 2013):

- descriptive studies of the governmental accounting reforms (Coy, Tower, \& Dixon, 1994) and (Christiaens, 2000);

- empirical studies of the implementation of the accounting reforms (Christiaens, 1999; Jones \& Pendlebury, 2004);

- theories explaining why governments choose to adopt accrual accounting (Lüder, Jones, \& Chan, 1992).

1 Has been renamed into International Public Sector Accounting Standards Board (IPSASB) in 2004. The members are: Australia, Argentina, Germany, France (Chair), UK, Israel, Japan, Canada, Malaysia, Mexico, New Zealand, Netherlands, Norway, South Africa, USA. 
The internationally accepted professional frameworks for public sector accounting, which are the base for the financial reports, are the International Public Accounting Standards (IPSAS) and Manual of Government Finance Statistics. IPSAS govern the recognition, measurement, presentation and disclosure requirements in relation to transactions and events in general purpose financial statements and were issued cash-based and as well for the accrual-based accounting. (International Public Sector Accounting Standards Board - IPSASB, 2007, pp. 5-8). The second mentioned accounting framework for government finance in EU is Manual on Government Finance Statistic. The Manual on Government Finance Statistic from 2001 describes a specialized macroeconomic statistical system (the GFS system) designed to support fiscal analysis. The manual provides the economic and accounting principles to be used in compiling the statistics and guidelines for the presentation of fiscal statistics within an analytic framework that includes appropriate balancing items. The process of introducing IPSAS is closely related to the existing reporting system based on the ESA 2010 statistic methodology. IPSAS emphasize the relation between ESA 2010 and the standards. Namely, IPSAS give great emphasis to the disclosure of data relating to the state sector, as this improves the quality of statements prepared on this basis. When IPSAS use the term "the state sector", this is referred to a statistical term defined in all significant statistical methodologies, while ESA 2010 is based on the accrual-based accounting system, thus establishing another link with IPSAS.

\section{The SWOT Analysis for Slovenian Public Sector Accounting Transformation}

\subsection{Experiences of Public Sector Accounting Reforms in Other Countries as Article Methodology}

Before assessing the potential transformation of Slovenian public sector accounting reform, let us briefly review the experiences of other counties; specially focusing on the principle (accrual/cash) accounting. The methodology used in the article is a combination of case studies and implementation of a simple SWOT matrix. There are several documents (articles, books, PhD theses, etc.) presenting cases of other countries that have, to a certain extent, already transformed the accounting in public sector, few of them even in budgeting, using accrual principle. Accrual accounting is actually not clearly defined and unequivocal concept; it is more an umbrella term to design a wide range of solutions. In some countries, it replaces traditionally budgetary accounting, elsewhere it means pure accrual accounting. There are also countries that had implemented accrual reporting together with cash reporting or commitment-based budgeting or countries with accruals data for management control purpose and finally countries with some sort of accrual-based management accounting for specific class of inputs within an otherwise traditional budgeting-accounting system (Anessi-Pessina, Nasi, \& Steccolini, 2008). 
The most frequently presented cases are those of New Zealand, Canada and UK, nevertheless Sweden and Australia should be mentioned. Throughout the 1980s Canadian governments significantly changed their financial reporting practice, moving from cash to accrual accounting and from separate accounting reporting to consolidated financial statements, nevertheless there were several political obstacles during the reforming process. Also New Zealand's implementation of the new financial management system is generally regarded as a success. At the start of the implementation there was a general dissatisfaction with the status quo. Sustained political and senior management commitment encouraged most public sector managements to welcome the change. An emphasis on communications and a careful ordering of the process ensured that risk was well managed (International Federation of Accountants - IFAC, 1994; Brandon, 2007). Later date researches report that Canada and New Zealand as well as UK and Australia have already accepted accruals use in both, financial reporting and in the budgeting. Countries have different experiences in conducting public sector accounting reforms while the area is very complex and contains many factors that could potentially affect the reform course and the results of the reforms themselves (Vašiček et al., 2008). Besides before mentioned countries, the accrual accounting has been implemented in Romania and France, while many other countries consider the accounting reform of public sector accounting (Austria, Macedonia, etc.).

Similar to the conclusions in the international comparative study by Brusca and Candor (2002), but additionally having taken into account transition countries as well, study by Roje (2007) concluded that it is especially in AngloSaxon countries where the accrual criterion predominates in public sector accounting, while Continental European countries are still in the process of converting to accrual accounting for both reporting and budgeting. Typically, the latter countries have so far adopted modified cash or modified accrual systems instead of complete or full accrual systems. According to Roje (2007), the data concerning countries in transition (for example Poland, Slovakia, Check Republic, Romania, Croatia), pointed out several discrepancies among the set of countries as far the process of adopting more complex accounting basis was concerned. This drew to the conclusion that the transformation stage towards adopting accruals in governmental accounting and reporting in a chosen set of transitions countries was characterized by accounting basis inconsistency.

Croatia has gone through differentstages and has modified accrual accounting principle in public sector. From 2002 Croatia has had its own accounting framework set up as a law-based system and has not had national public sector accounting standards developed, nor has applied accruals in government accounting system, nor has had IPSAS enacted as obligatory (but only recommended by the legislation), has complied certain existing accounting procedures with those recommended in IPSAS. The gradual transition from cash to accruals in the government financial reporting led Croatia 
towards the introduction of accruals in governmental financial reporting, the reconciliation and eventual consistency of accounting basis adopted for financial reporting with the accounting basis adopted for the budget, and the reconciliation and presentation of differences between statistics' reports on public expenditures' and the amounts in financial statements (Roje, Vašiček, \& Hladika, 2012).

But not all countries recognize positive effects of public sector accounting transformation, despite the fact that the appropriateness of accrual accounting adoption seems to be taken for granted and is perceived as self-evident. The literature review has brought us to several publications that highlight the negative consequences and problems in public sector accounting transformation, like Aiken and McCrea (1992), Pallot (1990), Parker and Guthrie (1993). Specially, Parker and Guthrie has argued the comparative lack of studies considering the application and consequences for the wider community. There are also some authors estimating the performance of transformation the public sector accounting in certain countries (like Ryan, Guthrie, \& Day, 2007; Lapsley, Mussari, \& Paulsson, 2009) that highlight the assumptions of the commonality of the accrual accounting technical and managerial applications in different contexts. The argument is that the accounting should be a context neutral accounting technique, which is applicable in many different contexts, situations and traditions, while in practice is unavoidable to face different historical roots. Understanding of the past, present and future of government accounting cannot thus be separated from understanding of what can be called accounting regime. Nevertheless, the accounting and reporting is the area in which serious weaknesses can still be found in most Central and Eastern European countries. While their budget classification system does not yet conform to international standards, it is a question if the ideology behind the development of international accounting system (GFS or IPSAS) can be understood in terms of a uniform and political neutral set of standards based on accounting theories developed by the accounting profession in the Anglo-Axon tradition, and which may be universally applied in any country in the world (Antipova \& Bourmistrov, 2013).

\subsection{The Arguments for Potential Transformation of the Public Sector Accounting System}

Nowadays, Slovenia is coping with serious public finance problems, concerning public deficit and debt. Strengthening the fiscal framework and increasing the effectiveness of public expenditure is one of the most important measures of National reform programme 2015-2016 (Government of the Republic of Slovenia, 2015), nevertheless the reduction of general government deficit below $3 \%$ of GDP and public debt below the current amount of $80.9 \%$ of GDP, stay at the head. In this context, several commitments were given to the EU, outstanding the enforcement of Fiscal Rule Act and amendments to Public Finance Act and Accounting Act, which should further determine budgetary 
planning in accordance with the requirements for budgetary framework of Member State (2011/85).

In this context, Slovenian Ministry of Finance announced the engagement in Strategy for the Development of Public Administration 2015-2020 in Slovenia (Chapter 6.8. Efficient use of resources) that was presented as independent country's development document but as a part of the National reform programme 2015-2016. The idea bases on program budgeting that was first implemented in the general government budget for 2001 according to this classification. The next reform step (2010-2012) tried to upgrade the budgetary methodology towards creating objectives, targets and indicators, which are the part of the budget documentation and as the key factors for decision and making of budget allocations. The program budgeting was upgraded into performance-based budgeting, which should provide a more precise view of public finance situation - especially regarding the questions about where we are now, what are the main issues, what are the main objectives, how social welfare has increased etc. The purpose of the program classification upgrading was to link the objectives and results of the program budgeting, and to connect them into the more efficient delivery of public services. Complementary, the public sector entities (budgetary users) should formulate their own set of indicators for monitoring the realization of their business results and long-term objectives. The program financing and management in public sector was a precondition for Slovenia to participate in the international institutions, like the International Monetary Fund, European Union and to increase the competitiveness of its economy when entering the European and global associations.

The program budgeting was established at the national level by upgrading the supporting information system of the Ministry of Finance in the general government budget for 2011, while this information system does not support other state treasuries in their budgeting and performance evaluation. There are several reasons why program budgeting has not been implemented in other state treasuries: inadequate legislation and lack of a strategic development framework at the national and municipal level, inadequate connection of development and program budgeting, the system of national accounts not providing support to targeted budget, etc.

Adding all the listed arguments to the fact, that Slovenian framework for the public sector accounting and preparation of financial statements has not been reformed since the adoption in 2000, should be indicative of need for transformation. Slovenian framework for the public sector accounting and preparation of financial statements for public sector entities consists of the Public Finance Act (in Slovenian: Zakon o javnih financah) and the Accounting Act (in Slovenian: Zakon o računovodstvu) as well as their implementing regulations. The Public Finance Act is the legal basis for budgetary and financial planning and execution while the Accounting Act enacts the book-keeping (recording) of the transactions caused by budget execution. 
"The provisions of the Accounting Act shall apply to bookkeeping and preparing annual reports for the 4 main entities; state, municipal budgets, indirect and direct budget users, the Medical Insurance Institute of Slovenia and Institute for Pension and Disability of Slovenia." (Article 89 of the Public Finance Act). Annual report comprises the balance sheet, the income statements, the notes to the Financial Statements, and business report Article 21 of the Accounting Act). The financial statements of the four public finance treasuries in Slovenia are prepared on the principle of cash flow. The financial plans of the state, the municipal and both insurance funds (ZPIZ and ZZZS) prepare, accept and implement according to the principle of cash flow. The Accounting Act on the other hand prescribes accounting for the indirect budgetary users based on the principle of cash flow and the accrual principle as well. In Slovenia direct and indirect budgetary users keep the books and prepare the financial statements according to the cash flow principle, while the indirect budgetary users do both; according to the cash but also accrual principle. The duality is used from the enforcement of the Accounting Act, while the double book-keeping causes a lot of additional work, the confusion of the accounting information receivers, the lack of transparency and finally a lot of reporting problems (Jovanović, 2013).

The accounting system of Slovenian public sector is the modified version of accounting system based on the cash-flow principle. Researching the public sector accounting legislation reveals that the public entities in Slovenia do prepare their financial reports on the cash flow basis but are simultaneously obliged to prepare it on accrual principle in some cases. As the reforming process of public sector (known as Public Sector Management) in general and the public sector accounting has been going on for a couple of decades, Slovenia has started to reconsider the possibility of modifying the accounting principles. In the last years, all the international professional analyses have exposed the accrual principle on the top of the public sector accounting profession because of the positive effects of this approach, among those the need and requirement for complete information for users of financial reports in advance (Zafreda, 2010).

\subsection{The Potential Implementation of Accrual Accounting in Slovenian Public Sector Accounting - SWOT Analysis}

Several sources prove the trend of public accounting leans towards the transition from cash flow to accrual principle. In general, the income and expenditure statements based on cash flow principle facilitate only yearly budget monitoring and may subsequently cause financial instability. The cash flow accounting is appropriate in circumstances where the minority of liabilities are long-term. Lately, countries are facing the increasing long-term liabilities such as the liabilities for the social security, the unemployment and the pensions. Nevertheless, if the budget revenues and expenditures are 
recorded according to the principle of cash flow, general government deficit is conceived on the same principle.

The accounting based on accrual principle enables transparent business monitoring, including claims and liabilities, which is not possible using cash flow principle accounting. Finally, the public sector accounting reform is only a part of the public management changes required. The accounting, cash or accrual based, is only one of many "business" functions in the public sector as the system. That is why the accountant will have to work closely with top and line management to ensure they have the financial information that they require to enable them fulfilling their responsibilities effectively.

Only a few resources report Slovenian public sector transformation or reforms in this field. According to those, Slovenia is considering two approaches to accrual accounting transition; the immediate adoption of accrual-based accounting or gradual transition (adoption). The gradual transition should be understood in the manner that in the first phase, all public finance funds continue to use cash-based accounting for preparing their books of account and for recording income and other receipts as well as expenses and other outflows, while all direct and other indirect budget users both at the state and local level begin applying accrual-based accounting methods. Despite the fact which of those will be chosen by the profession (nowadays divided into two opposite sides), similar steps have to be taken in order to achieve goal; transition on accrual-based accounting. There are also two possibilities as far as legal settlement is concerned. On one side, current accounting policies used by direct budget users or certain users of the unified chart of account in their bookkeeping and preparing of financial statements can simply be rolled-out to include budgets, public funds and direct budget users, utilising national accounting policies or the entirely of the International Public Sector Accounting Standards can be adopted (Janc, 2011).

Table 1: Strengths, weaknesses, opportunities and threats of Slovenian public sector accounting transformation towards accrual accounting

\begin{tabular}{|l|l|}
\hline Strengths: & Weaknesses: \\
- Accountability and financial management & - Historical background ("Accounting sediments") \\
transparency & - Lack of accounting knowledge \\
- Better management of assets and liabilities & - Lack of accounting definitions and \\
- Registering receivables from exchange and non- & interpretations \\
exchange transactions and liabilities Financial & - Adjustment of IT systems and the chart of \\
reports more comprehensive, simple and easier & account redesigning \\
to understand & - Principle of matching revenues against costs in \\
- Better liquidity management & not applicable in public sector \\
& $\begin{array}{l}\text { - Use of asset, like infrastructure, military or } \\
\text { heritage not used to generate revenues leads to } \\
\text { problem of valuation and depreciation }\end{array}$ \\
& - Great costs in inappropriate time \\
\hline Opportunities: & Threats: \\
- Governments could measure its activities & - No real need or incentive for transformation or \\
- Enhance transparency & reform \\
- Entities could identify fully cost of their various & - The objectives of public sector differ from \\
activities & private sector \\
- Financial reporting comparability & - Obtaining political support \\
\hline
\end{tabular}

Source: own, 2015 
In Table 1 there are pros and cons implementation of accrual accounting for Slovenian public sector entities. According to the testifies from different countries around the world, studying literature and practical issues, we have offered a matrix of strengths, weaknesses, opportunities and threats that should be considered when facing public sector accounting transformation.

It is nowadays very important to know, that although the majority of sources indicate positive effects of the accrual principle, the implementation without structured, previous, assessment of the impacts, would be risky. Some authors argue that the ideology behind the development of international accounting systems (such as GFS or IPSASs) can be understand in terms of a uniform and political neutral set of standards based on accounting theories developed by the accounting profession in the Anglo-Saxon tradition and others, which may be universally applied in any country in the world (Mahat \& Azman Ali, 2014). But the issue is not so unilateral like it seems to be. Understanding of the past, present and the future, as well as accounting roots of the country is very important for transformation of public sector accounting rules. Appling this knowledge for Slovenia, we should say that transformation or some kind of reformation of public sector accounting would be necessary, while even strategic documents demonstrate the need for more performance oriented public spending. In this manner, we expect the political as well as professional will for further steps in improvement of the government's functions. Concerning evidence and experience of other countries, great effort should be done in reform implementation, considering impact assessment in advance.

\section{Conclusion}

Discussing public sector accounting in context of improving the government accounting and financial reporting brings inevitable question: What is the key reason and purpose of the public sector accounting transformation in Slovenia? While neither public finance nor accounting system have not changed since year 2000, Slovenia should systematically assess the impacts of any potential changes in this field. The experiences of several different countries show that accrual based accounting implementation is a difficult, expensive and long-term project with success depending on several factors. The persistence of national traditions on one side and the relevance of the public sector accounting to the national sovereignty on the other have played a significant role in other countries. We can claim that transformation towards accrual-based accounting would improve the informative value of the financial reports and consequently the cost measurement of supplied services and political programmes improvement, the better monitoring of assets, more accurate measurement of financial position and performance, etc. All of the above targets governance at the national level and might influence the budget accounting. However there could be some other supranational interests while the micro-accounting influences the EU level reporting, as well. 
At the EU level, it would assure debt and deficit data according demanded with ESA 2010 to control and assess the Maastricht Treaty criteria.

All of the above should be assessed by Slovenian decision-makers when considering public sector accounting transformation. Nevertheless, the reason for accounting transformation comes from the EU regulations (ESA 2010) or from the national level (performance budgeting), a certain degree of accrual accounting should be implemented. Finally, there is a question of budgetary accounting transformation. The significant trend towards accruals in financial statements of public sector entities has not resulted in accrual budgeting.

Tatjana Jovanovic, PhD, is an assistant professor at the Department of Economics and Management in the Public Sector, employed at the Faculty of Public Administration, University of Ljubljana since 2008. She began her career in the private sector, where she held managerial positions in accounting and finance departments. In 2006 she acquired a license for tax consultant at the Chamber of Tax Advisers and as a tax consultant at the Craft and Small Business Chamber of Commerce participated in many projects of legislation reforming. At the Faculty of Public Administration she gives lectures on Tax system, Public Finance, Economics of Public Enterprises and Institutions and Economics. Her research interests focus on public sector financial management, public sector accounting and auditing. 


\section{References}

Accounting Act (Zakon o računovodstvu). Official Gazette of Republic of Slovenia, No. 23/1999, 30/2002 - ZJF-C, 114/2006 - ZUE.

Aiken, M., \& McCrea, M. (1992). Full cost pricing and public sector reporting: alleviating undisclosed short-run measurement biases of 'user to pay' policies. Financial Accountability \& Management, 8(1), 13-34.

DOI: 10.1111/j.1468-0408.1992.tb00358.x

Anessi-Pessina, E., Nasi, G., \& Steccolini, I. (2008). Accounting Reforms: Determinants of Local Government Government's Choice. Financial Accountability \& Management, 24(3), 321-342.

DOI: $10.1111 / \mathrm{j} .1468-0408.2008 .00455 . x$

Antipova, T., \& Bourmistrov, A. (2013). Is Russian Public Sector Accounting in the Process of Modernization? An Analysis of Accounting Reforms in Russia. Financial Accountability \& Management, 29(4), 442-478. DOI: 10.1111/ faam.12021

Barton, A. (2004). How to Profit from Defence: A Study in the Misapplication of Business Accounting to the Public Sector of Australia. Financial Accountability \& Management, 20(3), 281-304. DOI: 10.1111/j.0267-4424.2004.00388.x

Broadbent, J., \& Guthrie, J. (1992). Changes in the Public Sector: A Review of Recent "Alternative" Accounting Research. Accounting, Auditing \& Accountability Journal, 5(2), 3-31. DOI: 10.1108/09513579210011835

Brusca, I., \& Condor, V. (2002). Towards the Harmonisation of Local Accounting Systems in the International Context. Financial Accountability and Management, 18(2), 38-160. DOI: 10.1111/1468-0408.00148

Brusca, I., Caperchione, E., Cohen, S., \& Manes Rossi, F. (2015). Public Sector Accounting and Auditing in Europe. IIAS Series: Governance and Public Management. DOI: 10.1057/9781137461346

Burkitt, B., \& Whyman, P. (1994). Public Sector Reform in Sweden: Competition or Participation? Political Quarterly, 65(3), 275-284. DOI: 10.1111/j.1467923X.1994.tb01542.x

Centre of Excellence in Finance. (2011). International trends in public sector accounting reforms, 2011 Annual Policy Conference, Ljubljana, Slovenia, April 20-22, 2011. Slovenia, Ljubljana.

Christiaens, J., \& Reyniers, B. (2009). Impact of IPSAS on Reforming Governmental Financial Information Systems: A Comparative Study (Working Paper D/2009/7012/52). University of Ghent: Ghent University, Department of Accountancy and Corporate Finance.

Christiaens, J. (1999). Financial Accounting Reform in Flamish Municipalities: An Empirical Investigation. Financial Accounting \& Management, 15(1), 21-40. DOI: $10.1111 / 1468-0408.00072$

Coy, D., Tower, G. \& Dixon, K. (1994). Public sector reform in New Zealand: The progress of tertiary education annual reports, 1990 - 92. Financial Accountability \& Management, 10(3), 253-261. DOI: $10.1111 / j .1468-0408.1994 . t b 00232 . x$

Fauziah, M., \& Azman Ali, N. (2014). Human Perspective on Cash and to Accrual Based Accounting System in Malaysia. Global Review of Accounting and Finance, 5(2), 1-15. Available at https://www.researchgate.net/ publication/269103688_Human_Perspective_on_Cash_to_Accrual_Based_ Accounting_System_in_Malaysia 
Government of the Republic of Slovenia. (2015). National reform programme 2015-2016. Retrieved from http://ec.europa.eu/europe2020/pdf/csr2015/ nгp2015_slovenia_en.pdf

Hepworth, N. (2003). Preconditions for Successful Implementation of Accrual Accounting in Central Government. Public Money \& Management, 23(1), 37-44. DOI: $10.1111 / 1467-9302.00339$

International Federation of Accountants - IFAC (2003). The Modernization of Government Accounting in France: The Current Situation (Occasional Paper, No. 6). New York: International Federation of Accountants.

International Public Sector Accounting Standards Board - IPSASB. (2007). Handbook of International Public Sector Accounting Pronouncements. New York: IFAC.

Janc, M. (2011). Challenges of adopting accrual-based accounting in place of cashbased accounting. International trends in public sector accounting reforms. Ljubljana: Centre of Excellence, Ministry of Finance.

Jones, R., \& Pendlebury, M. (2004). A theory of published accounts of Local Authorities. Financial Accountability \& Management, 20(3), 305-325. DOI: $10.1111 / \mathrm{j} .0267-4424.2004 .00386 . x$

Jovanović, T. (2013). Public sector accounting reform. Paper presented at the 21st International Conference, "Regionalisation and Inter-regional Cooperation", 16. -18. May 2013, Serbia, Belgrade.

Kara, E. (2012). Financial Analysis in Public Sector Accounting. An Example of EU, Greece and Turkey. European Journal of Scientific Research, 69(1), 81-89. Available at http://www.slideshare.net/yudi_syah/Financial-analysis-in-publicsector-accounting-an-example-of-eu-greece-and-turkey

Lapsley, I., Mussari, R., \& Paulsson, G. (2009). On the Adoption of Accrual Accounting in the Public Sector: A Self-Evident and Problematic Reform. European Accounting Review, 18(4), 719-723.

DOI: $10.1080 / 09638180903334960$

Lüder, C., Jones, R., \& Chan, J. (1992). A Contingency Model of Governmental Accounting Innovations in the Political-Administrative Environment. Research in Governmental and Non-profit Accounting, 7, 99-127. Available at http://citeseerx.ist.psu.edu/viewdoc/download?doi=10.1.1.454.3070\&гер=гер1\& type $=p d f$

Lüder, C., \& Jones, R. (2003). Reforming Governmental Accounting and Budgeting in Europe. Frankfurt: Fachverlag Moderne Wirtschaft.

Mahat, F., \& Azman Ali, N. (2014) Human Perspective on Cash to Accrual Based Accounting System in Malaysia. Global Review of Accounting and Finance, 5(2), $1-15$.

International Monetary Fund - IMF. (2001). Manual on Government Finance Statistic. Available at http://www.imf.org/external/np/sta/gfsm/

Pallot, J. (1990). The Nature of Public Assets: A Response to Mautz. Accounting Horizons, 4(2), 79-85.

Parker L. D., \& Guthrie, J. (1993). The Australian public sector in the 1990s: New accountability regimes in motion. Journal of International Accounting, Auditing and Taxation, 2(1), 59-81. DOI: 10.1016/1061-9518(93)90015-L

Public Finance Act (Zakon o javnih financah). Official Gazette of the Republic of Slovenia, No. 79/1999, 124/2000, 79/2001, 30/2002, 110/2002 -ZDT-B, 56/2002 - ZJU, 127/2006 - ZJZP, 14/2007 - ZSPDPO, 109/2008, 49/2009, 38/2010 - ZUKN, 107/2010. 
Richard, A. (2002). Budgetary and Financial Management Reform in Central and Eastern Europe. Models of Public Budgeting and Accounting Reform, 2(S1), 81-114. Paris: OECD.

Roje, G., Vašiček, V., \& Hladika, M. (2012). The perspectives of IPSASs introduction in Croatian public sector. Public Sector Performance Management (1), 25-43.

Roje, G. (2007). The Role of Accrual Financial Reporting and Budgetary Basis in Public Sector Financial Management Reforms: Croatian Experience and International Trends. Paper presented at the 8th International Conference, Improving business reporting: new rules, new opportunities, new trends, November 24-25. Italy, Milano.

Ryan, C. M., Guthrie, J., \& Day, R. (2007). The Politics of Financial Reporting and the Consequences for the Public Sector. Abacus, 43(4), 474-487. DOI: $10.1111 / \mathrm{j} .1467-6281.2007 .00243 . \mathrm{x}$

The Institute of Internal Auditors - IIA. (2011). Supplemental Guidance: Public Sector Definition. USA, Altamonte Springs.

Vašiček, V., Vašiček, D., \& Roje, G. (2008). Development of Governmental Accounting in Croatia. Paper presented at the 12th World Congress of Accounting Historians. Congress Proceedings, Istanbul: Association of Accounting Historians and Finance Academicians (AAFA).

Retrevied from https://www.researchgate.net/profile/Gorana_Roje/ publication/225292798 Development_of Governmental_Accounting in Croatia/ links/09e415115122446fbd000000.pdf

Zafreda, J. I. (2010). The transition of international accounting standards for the public sector in the financial statements of public entities - such as Slovenia (PhD - doctoral thesis). Ljubljana: University of Ljubljana, Faculty of Economics. 


\section{Ali naj Slovenija reformira računovodstvo javnega sektorja?}

Računovodstvo javnega sektorja je organiziran sistem za zbiranje in evidentiranje poslovnih dogodkov ter pripravo računovodskih poročil vjavnem sektorju. Bistvena naloga slednjega je odgovorna in finančno transparentna podaja informacij uporabnikom, ki so povezani z javnimi ustanovami, medtem ko je glavni cilj pridobiti transparentno in popolno oceno poslovnih aktivnosti in lastnine porabnikov javnih sredstev. Celoten sistem javnega računovodstva neke države je sestavljen iz številnih podsistemov oz. računovodstev posameznih organizacij javnega sektorja. Organizacije oz. subjekti javnega sektorja pa se financirajo v glavnem iz obveznih dajatev in opravljajo javne (netržne) storitve. Gre za vlado in vse javno nadzorovane ali javno financirane agencije, službe ter družbe in druge subjekte, ki zagotavljajo javne programe, dobrine ali storitve.

Zadnja desetletja je javni sektor doživel številne spremembe, zlasti pod vplivom koncepta t. i. novega javnega menedžementa (NJM), ki je zajel tako organizacijske in vodstvene kot tudi računovodske reforme znotraj posameznih držav. Spremembe so imele za cilj večjo učinkovitost in odgovornost za izvedbo javnih storitev, za kar pa se, po zgledu računovodenja v zasebnem sektorju, izhaja iz večjega pomena računovodenja po obračunskem načelu (načelo nastanka poslovnega dogodka) in manjšanja pomena računovodenja po načelu denarnega toka. Reforme javnega računovodstva pomenijo operativne, vendar tudi organizacijske, kadrovske in managerske spremembe, ki sledijo ideji spremembe načela računovodenja iz načela denarnega na obračunsko načelo. Pregled literature pokaže, da se računovodstva držav razlikujejo tako med državami kot tudi znotraj držav EU. Raznolikost se giblje od temeljnih razlik v sistemih evidentiranja do različnih pravil za merjenje kategorij in zahtev po razkritjih. $\vee$ nasprotju z večino literature, ki osvetljuje področje reformnih trendov javnega računovodstva in zagovarja računovodenje po obračunskem načelu kot edino primerno, pa najnovejše študije priznavajo, da je bila večina že opravljenih reform v veliki meri produkt posameznih držav, tako v obsegu in časovnem načrtu kot v usmeritvah za izvajanje ter da so imele tudi slednje določene pomanjkljivosti.

Računovodsko poročanje v javnem sektorju poteka v skladu z mednarodnimi standardi za javno računovodstvo (International Public Accounting Standards - IPSAS) in Priročnikom za državno finančno statistiko. Proces uvajanja IPSAS je tesno povezan z obstoječim sistemom poročanja, ki temelji na metodologiji statističnega ESA 2010, saj standardi poudarjajo odnos med ESA 2010 in standardi. Poleg IPSAS je pomemben računovodski okvir za vladne finance $v$ 
EU tudi The Manual on Government Finance Statistic, ki opisuje specializirani makroekonomsko statistični sistem (GFS sistem), ki podpira fiskalno analizo.

Članek analizira prednosti in slabosti posameznega načela računovodenja, pravne podlage in standarde ter prakse držav, ki so z reformnimi programi usmerjenimi k uvedbi obračunskega načela že imele izkušnje. Na podlagi analizirane literature o izkušnjah drugih držav, ki osvetljujejo prednosti in slabosti posameznega načela računovodenja ponuja članek SWOT analizo izvedbe potencialne reforme. Študije kažejo, da so številne evropske države reformirale javno računovodstvo, pri čemer je poudarek reform zlasti na uvedbi obračunskega načela ter IPSAS. Izkazalo se je, da obračunsko načelo prevladuje v računovodstvu anglosaških držav, medtem ko v kontinentalnih državah ta pretvorba še vedno poteka, zlasti preko vmesnih računovodskih sistemov kot sta modificirani sistem denarnega načela ali modificirani sistem obračunskega načela. Obstajajo številni viri, ki predstavljajo primere reform računovodskih sistemov drugih držav, ki so v takšni ali drugačni obliki uvedle obračunsko načelo. Obračunsko računovodstvo ni natančno opredeljen in nedvoumen koncept, saj gre bolj za krovni izraz za oblikovanje širokega spektra rešitev. V nekaterih državah nadomešča tradicionalno proračunsko računovodstvo, drugod pa pomeni le računovodstvo javnega sektorja. Obstajajo pa tudi države, ki so poleg računovodenja po obračunskem načelu uvedle tudi računovodsko poročanje po načelu denarnega toka ali tudi računovodsko poročanje, ki temelji na k ciljnem usmerjenem proračunu ali poročanje po obračunskem načelu za potrebe managerske kontrole, pa tudi države z neke vrste računovodenjem po obračunskem načelu za določene kategorije, sicer pa imajo tradicionalno proračunsko računovodenje.

SWOT analiza je pokazala, da ima slovenski sistem javnega računovodenja številne slabosti, ki se kažejo kot zgodovinsko ozadje (usmerjeno v načelo denarnega toka), pomanjkljivo znanje računovodij, pomanjkanje definicij računovodskih kategorij ter interpretacij, potrebo po prilagoditvah IT sistemov ter kontnih načrtov, itn. in bistveno manj prednosti, ki se kažejo v glavnem kot odgovoren in transparenten menedžement, boljši menedžement sredstev in obveznosti ter terjatev in obveznosti. Matrika je pokazala, da se kažejo tudi določene priložnosti kot npr. boljše možnosti za merjenje aktivnosti javnega sektorja, zagotavljanje transparentnosti, uvedba stroškovnega računovodstva, itn. Med grožnjami pa je zaznati stanje, kjer ni prave potrebe in spodbud za reforme, očitno je pomanjkanje politične volje za spremembe ter dejstvo, da se cilji javnega sektorja razlikujejo do ciljev zasebnega sektorja.

Glede na pregled literature oz. dobrih praks ter opravljeno SWOT analizo se postavlja vprašanje, ali bodo slovenski odločevalci šli v reforme računovodstva javnega sektorja. Ne glede na to, ali prihajajo spodbude od zunaj (ESA 2010) ali od znotraj (programski proračun), se kaže, da bo določeno stopnjo obračunsko naravnanega računovodenja potrebno vpeljati. Končno, obstaja vprašanje preobrazbe proračunskega računovodstva, kar pa se (glede na skromne izkušnje drugih držav) ne bo zgodilo prav kmalu. 